\title{
CONSTRUCTION AND CHARACTERIZATION OF A GLYCOPROTEIN E DELETION MUTANT OF BOVINE HERPESVIRUS TYPE 1.2 STRAIN ISOLATED IN BRAZIL
}

\author{
Ana C. Franco ${ }^{1,2 *}$; Frans A.M. Rijsewijk ${ }^{3}$; Eduardo F. Flores ${ }^{4}$; Rudi Weiblen ${ }^{4}$; Paulo M. Roehe ${ }^{1,5}$ \\ ${ }^{1}$ Centro de Pesquisas Veterinárias Desidério Finamor, Eldorado do Sul, RS, Brasil. ${ }^{2}$ Universidade Luterana do Brasil, Canoas, RS, \\ Brasil. ${ }^{3}$ Institute for Animal Science and Health, Division of Infectious Diseases and Food Chain Quality, (ID-Lelystad), \\ Lelystad, The Netherlands. ${ }^{4}$ Centro de Ciências Rurais, Universidade Federal de Santa Maria, Santa Maria, RS, Brasil. \\ ${ }^{5}$ Instituto de Ciências Básicas da Saúde, Universidade Federal do Rio Grande do Sul, Porto Alegre, RS, Brasil
}

Submitted: March 26, 2001; Returned to authors for corrections: July 02, 2001; Approved: April 06, 2002

\begin{abstract}
This paper describes the construction and characterization of a Brazilian strain of bovine herpesvirus type 1.2a (BoHV-1.2a) with a deletion of the glycoprotein $\mathrm{E}(\mathrm{gE})$ gene. The deletion was introduced by cotransfection of a deletion fragment containing the $5^{\prime}$ and $3^{\prime} \mathrm{gE}$ flanking regions and genomic DNA of wild type BoHV-1 into bovine cells. Isolation of $\mathrm{gE}$ deletion mutant was performed by immunoperoxidase staining with an anti-gE monoclonal antibody. Viral clones were plaque purified and further examined by restriction endonuclesase digestion and Southern blot hybridization. This gE deletion mutant will be evaluated as a vaccinal virus, in order to determine its potential use for a differential vaccine.
\end{abstract}

Key words: infectious bovine rhinotracheitis/infectious pustular vulvovaginitis, BoHV-1, deletion mutant, differential vaccine

\section{INTRODUCTION}

Bovine herpesvirus 1 (BoHV-1), a major pathogen of cattle, is the agent of infectious bovine rhinotracheitis/infectious pustular vulvovaginitis virus (IBR/IPV) and it is associated to a number of other clinical syndromes, including pustular balanopostitis, abortion, infertility and conjunctivitis (3). BoHV1 strains can be subdivided into three distinct genotypes, BoHV1.1, BoHV-1.2a and BoHV-1.2b (9). Genotypes 1.1 and 1.2a are usually more virulent and can be associated to abortions, while strains from genotype $1.2 \mathrm{~b}$ are usually less virulent and have not been related to abortions $(2,10)$. Although such genomic differences do reflect pathogenic and antigenic differences, to date there is only one recognized antigenic group (16).

The BoHV-1 genome consists of a double stranded DNA molecule of about $135 \mathrm{~kb}$, composed of a unique long $\left(\mathrm{U}_{\mathrm{L}}\right)$ and a unique short regions $\left(\mathrm{U}_{\mathrm{S}}\right)$, flanked by an internal (IR) and a terminal (TR) inverted repeat sequences (13). The viral genome encodes approximately 70 different proteins, of which eleven are glycoproteins. One of these glycoproteins, glycoprotein E $(\mathrm{gE})$, is encoded by a gene located within the $\mathrm{U}_{\mathrm{S}}$ region $(11,17,18)$. Glycoprotein $\mathrm{E}$ is not essential for viral replication, but in vitro growth analysis of viral mutants show a decreased cell-to-cell spread and smaller plaque size for $\mathrm{gE}$ negative viruses $(11,17)$. In addition, $\mathrm{gE}$ deletion in vivo has been related to a decreased virulence in calves $(1,14,15)$.

Both spontaneous and artificially induced viral mutations have successfully been used in animal vaccine production. An european gE negative ( $\left.\mathrm{gE}^{-}\right)$BoHV-1.1 strain has been used as a differential vaccine for the control of BoHV-1 infections, allowing the differentiation between the immune responses of infected and vaccinated animals $(1,14,15)$. Although BoHV-1 isolates are genetically stable, small antigenic variations may occur. Therefore, autochtonous isolates used for animal vaccine production may be more efficacious as vaccinal strains when compared to non-autochtonous strains. In this study we describe the deletion of the $\mathrm{gE}$ gene from a Brazilian isolate of BoHV-1.2a, a candidate strain for a differential vaccine.

\footnotetext{
* Corresponding author. Mailing address: Instituto de Ciências Básicas da Saúde, Universidade Federal do Rio Grande do Sul. Caixa Postal 2076. 90001970, Porto Alegre, RS, Brasil. E-mail: proehe@orion.ufrgs.br
} 


\section{MATERIALS AND METHODS}

\section{Virus strain and cells}

The BoHV-1.2 strain SV265 (genotype 1.2a), isolated from an animal with respiratory disease during an outbreak of IBR in São Borja, Rio Grande do Sul, Brazil. The virus was multiplied in Madin Darby bovine kidney (MDBK) or in embryonic bovine trachea (Ebtr) cells. Cell cultures were kept in Eagle's minimal essential medium (EMEM) supplemented with 5\% to $10 \%$ fetal calf serum, $0.05 \%$ yeast lactalbumin hydrolysate, $2 \mathrm{mM}$ glutamine and antibiotics (100 iu/ml penicillin, $100 \mu \mathrm{g} / \mathrm{ml}$ streptomycin and $20 \mathrm{iu} / \mathrm{ml}$ mycostatin).

\section{Viral DNA extraction}

Sub-confluent cells grown in $900 \mathrm{~cm}^{2}$ roller bottles were infected with virus at a multiplicity of infection of 0.1 to 1 . Approximately 36 hours after infection, when cytopatic effect (CPE) was evident in 90-100\% of the cells, the supernatant was removed, clarified at $5000 \mathrm{x} \mathrm{g}$ for 20 minutes and centrifuged at $100000 \times \mathrm{g}$ for two hours at $4^{\circ} \mathrm{C}$. The viral pellet was resuspended in TE (Tris 10mM, EDTA 1mM, pH 7.4) and treated with sodium dodecil sulfate and proteinase $\mathrm{K}$ (final concentrations of $1 \%$ and $100 \mu \mathrm{g} / \mu \mathrm{l}$, respectively) for one hour at $37^{\circ} \mathrm{C}$. The viral DNA was extracted with equilibrated phenol, precipitated with ethanol, resuspended in TE $\mathrm{pH} 7.4$ and stored at $4^{\circ} \mathrm{C}(12)$.

\section{Polymerase chain reaction (PCR) and clonings}

Amplification and cloning of the 5' and $3^{\prime} \mathrm{gE}$ flanking regions were performed to obtain the gE deletion fragment, according to the scheme shown in Fig. 1. The primers used for amplification of the 5'region were P1: 5'-CGACTGCTTCGTTATGCTGC-3' and P2: 5'-GCGAGACCCATTTAACAACCC-3'. For the 3' region, primers were P3: 5'- TGTGCCGTCTGACGGAAAGC-3' and P4: 5' -AATCCCCTCCTTCCCCTCC-3'. All primers sequences were obtained from the database (7). The predicted sizes of $5^{\prime}$ and $3^{\prime}$ gE flanking regions were 1100 base pairs (bp) and $900 \mathrm{bp}$, respectively, and the conditions for amplification were: $80^{\circ} \mathrm{C}$ for 30 seconds, $94^{\circ} \mathrm{C}$ for 1 minute, $60^{\circ} \mathrm{C}$ for 1 minute and $72^{\circ} \mathrm{C}$ for 1 minute. This cycling profile was repeated 15 times and followed by additional 23 cycles as described: $94^{\circ} \mathrm{C}$ for 1 minute, $60^{\circ} \mathrm{C}$ for 1 minute and $72^{\circ} \mathrm{C}$ for 1 minute. A final extension step at $72^{\circ} \mathrm{C}$ for 7 minutes was applied.

All amplification reactions were performed using SV265 isolated DNA as template and both amplicons were examined by restriction enzyme analysis. Data obtained was compared with expected fragments based on previously reported BoHV-1 sequences (7). Amplicons were separately cloned in plasmid pCR 2.1 (TA Cloning Kit, Invitrogen), following the manufacturer's specifications. One of the clones containing the $5^{\prime} \mathrm{gE}$ flanking region was digested with restriction enzymes, isolated from an agarose gel and subsequently ligated in one of the $3^{\prime} \mathrm{gE}$ clones in order to produce the recombinant plasmid containing both $\mathrm{gE}$ flanking regions ( $\mathrm{gE}$ deletion fragment).

\section{Construction and isolation of the $\mathrm{gE}^{-}$recombinant}

Co-transfections were performed by the calcium phosphate method (4). Wild type viral DNA $(2 \mu \mathrm{g})$ was co-transfected with $2 \mu \mathrm{g}$ of the gEdeletion fragment in presence of carrier DNA (16 $\mu \mathrm{g}$ of salmon sperm DNA) in Ebtr cells.

Forty eight hours after co-transfection, plates were frozen and thawed to liberate cell-associated virions. Supernatants of co-transfection reactions were then used to infect 96 well plates with pre-formed Ebtr monolayers in order to isolate recombinant viruses. After visualization of cytopathic effect (CPE) on Ebtr cells, plates were fixed with $4 \%$ paraformaldehyde in phosphate buffered saline (PBS; 8.5g NaCl, 1.55g Na $2 \mathrm{HPO}_{4}, 0.23 \mathrm{~g} \mathrm{NaH} \mathrm{PO}_{4}$, $\mathrm{pH} 7.2$ per liter) and the immunoperoxidase monolayer assay (IPMA) was performed as described (6), using the anti-gE monoclonal antibody number 75 (5) as the primary antibody. Wells with unstained viral plaques were recorded, the supernatants collected and used to infect 96-well plates with Ebtr monolayers.

IPMA was performed until the complete isolation (that is, no stained viral plaques) of $\mathrm{gE}^{-}$virus from wild type virus. The $\mathrm{gE}^{-}$virus was then submitted to three additional cycles of plaque purification in 6-well plates under semi-solid medium (1\% of agarose in EMEM).

\section{Restriction enzyme analysis of wild type and gE- viral DNA}

DNA from wild type and $\mathrm{gE}^{-}$virus was isolated as described above and restriction enzyme analysis was performed according to standard methods (12). Viral DNA was digested with HindIII and EcoRI, the fragments were separated on a $0.5 \%$ agarose gel and stained with ethidium bromide following standard procedures (12).

\section{Southern blot}

Digested viral DNA was transferred to hybridization transfer membrane GeneScreen Plus (Biotechnology Systems) according to standard methods (12). The gE probe was the $2026 \mathrm{bp}$ insert of plasmid p318 that harbors the complete $\mathrm{gE}$ open reading frame from the AluI site up to the HincII site. This fragment starts 52 nucleotides upstream the gE start codon and ends 130 nucleotides downstream the gE stop codon. The $2026 \mathrm{bp}$ fragment was labeled with ${ }^{32} \mathrm{PdATP}$ using a nick translation kit (Boehringer Manheim) according to the manufacturer's instructions.

Membrane hybridization was performed with $10 \mathrm{ng}$ of the probe diluted in hybridization buffer, $\mathrm{pH} 7.2$ (0.5 $\mathrm{M}$ sodium phosphate buffer, $1 \mathrm{mM}$ EDTA, $7 \%$ SDS) at $65^{\circ} \mathrm{C}$ overnight. After two washing steps, the membrane was exposed to a storage phosphor screen (Molecular Dynamics) and the fluorogram was made using the fluorescence scanning system "storm" (Molecular Dynamics). 


\section{RESULTS}

\section{Construction of the $\mathrm{gE}^{-}$fragment}

The PCR of the 5'gE flanking regions originated an amplicon of the expected size (1100 bp). This fragment, denominated 5 ' $\mathrm{gE}$, was cloned in pCR 2.1 and examined by restriction enzyme analysis for orientation. The amplicon corresponding to the $3^{\prime} \mathrm{gE}$ flanking region however, gave rise to a fragment of $750 \mathrm{bp}, 150 \mathrm{bp}$ shorter than the expected size. This fragment was examined by restriction enzyme analysis and results carefully compared with previous published nucleotide sequences of other BoHV-1 strains (7). After ensuring that, despite its shorter size, the fragment corresponded to the desired region, it was subcloned along with the $5^{\prime} \mathrm{gE}^{-}$region. Two clones in the correct orientation, containing the $5^{\prime}-3^{\prime} \mathrm{gE}$ flanking regions, were selected and digested with restriction enzyme PstI to isolate the deletion fragment after gel electrophoresis. The deletion fragment contains, in total, about $1900 \mathrm{bp}$, corresponding to the 5' and 3'gE flanking regions, separated by 80 nucleotides, which correspond to the plasmid polylinker. This 80 nucleotides fragment harbors two EcoRI sites, one immediately downstream the $5^{\prime} \mathrm{gE}$ flanking region and one immediately upstream the $3^{\prime} \mathrm{gE}$ region. According to this approach, the induced deletion starts 135 nucleotides upstream the gE start codon and ends 20 nucleotides downstream the gE stop codon.

\section{Co-transfection and isolation of deleted virus}

Co-transfection with viral DNA and the deletion fragment was performed in 6 well plates. About seven hundred viral

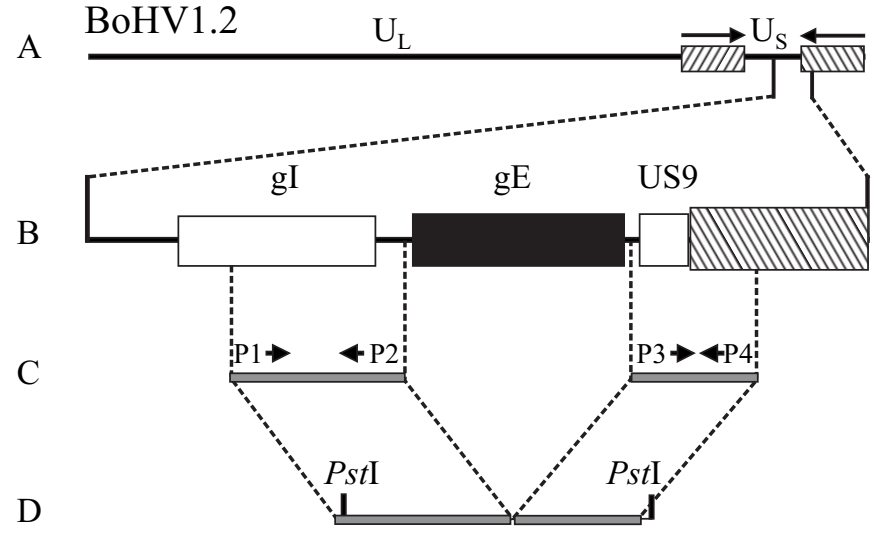

Figure 1. Schematic representation of the construction of the gE deletion fragment. A: The complete BoHV-1.2 genome, $\mathrm{U}_{\mathrm{L}}$ : unique long region, $\mathrm{U}_{\mathrm{s}}$ : unique short region, hatched boxes represent internal and terminal repeats; B: gE gene represented by the dotted box and flanked by the gI and US9 genes; C: amplified gE 5' and 3' flanking regions; D: gE deletion fragment, ligated in pCR2.1. P1-4: primers 1-4; PstI: restriction enzyme used to liberate the deletion fragment. plaques were obtained after co-transfection of Ebtr cells with wild type virus and the $\mathrm{gE}$ deletion fragment. Selection of $\mathrm{gE}^{-}$ virus was made by IPMA after infection of co-transfection supernatants in preformed Ebtr monolayers in 96 well plates. Two wells showing unstained viral plaques were selected and their supernatants were used to infect new Ebtr monolayers. After a new IPMA, completely unstained CPE was detected (data not shown) and the gE negative virus was submitted to three rounds of plaque purification.

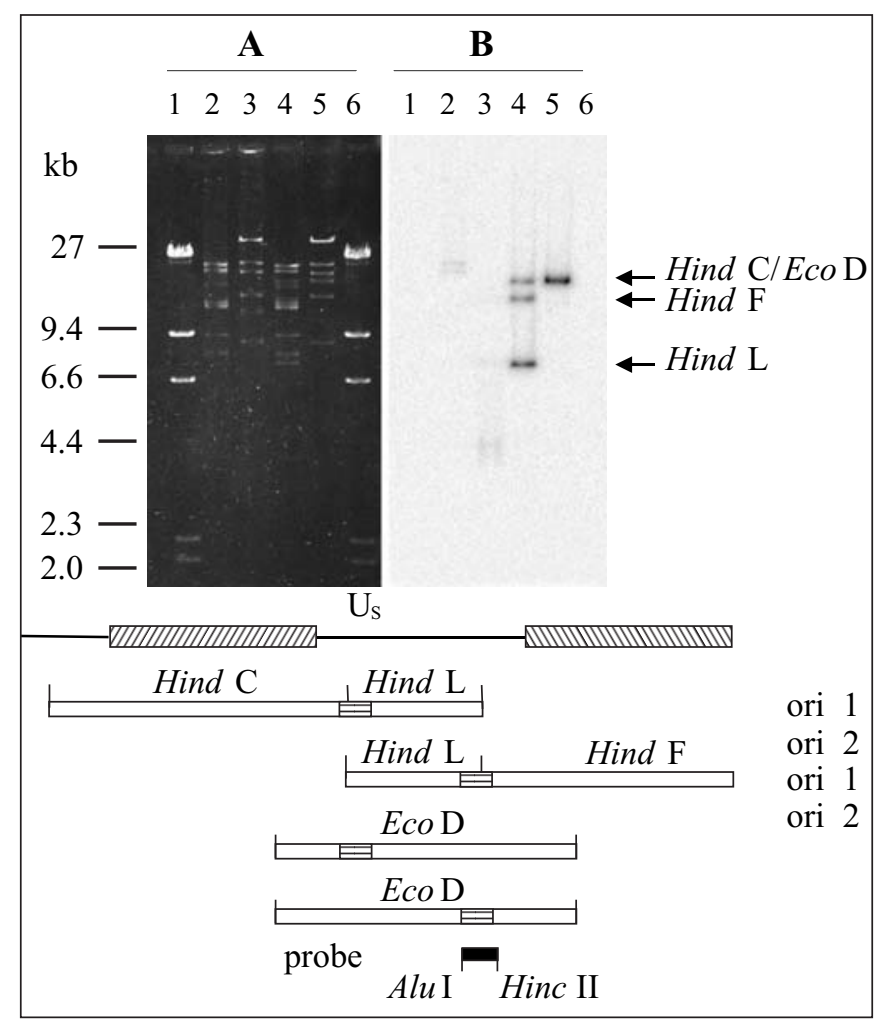

Figure 2. Genomic analysis of wild type and gE negative viral DNA. Panel A shows the restriction endonuclease fragments of gE negative (lanes 2 and 3 ) and wild type viral DNA (lanes 4 and 5). Viral DNA was digested with HindIII (lanes 2 and 4) and with EcoRI (lanes 3 and 5). Lanes 1 and 6 show the Lambda HindIII DNA size marker. Panel B shows the results of the hybridization with the $\mathrm{gE}$ probe on digested viral DNA shown in panel A. Specific hybridization is observed with wild type viral DNA (lane 4, Hind III C, F and L fragments and lane 5, EcoRI D fragment). The map bellow panels $A$ and $B$ shows the $U_{S}$ region, flanked by internal and terminal repeats (hatched boxes), and HindIII and EcoRI fragments which are surrounding the gE gene (dotted box). The map shows the two orientations (ori 1 and 2) of the $U_{S}$ region found with respect to the $\mathrm{U}_{\mathrm{L}}$ region. The black box represents the probe used in Southern blot analysis. The PstI restriction enzyme sites, used to obtain the probe, are indicated. 


\section{Restriction endonuclease analysis}

The results of the restriction endonuclease analysis are shown in Fig. 2, panel A. Digestion with HindIII showed the disappearance of the 7.2 kilobase (kb) fragment (HindIII L band) from the deleted viral DNA (panel A, lane 2). Due to the absence of the HindIII site in the gE gene, HindIII $\mathrm{C}$ and $\mathrm{F}$ bands also disappear in $\mathrm{gE}^{-}$viral DNA, giving rise to two new DNA fragments of about $22.2 \mathrm{~kb}$ (after fusion of Hind III C and L) and $19 \mathrm{~kb}$ (after fusion of bands $\mathrm{F}$ and $\mathrm{L}$ ). Digestion of $\mathrm{gE}$ negative viral DNA with EcoRI showed that the $17.6 \mathrm{~kb}$ fragment (denominated EcoRI D fragment) disappears and gives rise to two additional bands with about 11.6 and $4.2 \mathrm{~kb}$ (not visible on gel) (panel A, lane 3). Such genomic alterations were compatible with the loss of the expected $1.8 \mathrm{~kb}$ fragment corresponding to the $\mathrm{gE}$ gene and the insertion of new EcoRI sites in the deletion fragment. No other major genomic alterations could be detected in wild type or deleted viral DNA.

\section{Southern Blot}

Digested wild type and gE negative viral DNAs were blotted and probed with the whole gE open reading frame (Fig. 2, panel B). Wild type DNA showed specific hybridization with the expected fragments, which are HindIII C, F and L and EcoRI D bands (panel B, lanes 4 and 5, respectively). No specific hybridization was observed in gE negative viral DNA, except for a weak signal with the new HindIII 22.2 and $19 \mathrm{~kb}$ and with the new 4.2 EcoRI fragment. This weak reaction occurred due to the 130 nucleotides overlap of the gE probe downstream the gE stop codon.

\section{DISCUSSION}

The introduction of gene deletions, either naturally or by genetic engineering, has been used to provide potential candidate virus strains for vaccine development. Others have shown that $\mathrm{gE}^{-}$bovine herpesviruses may be suitable vaccine viruses in differential vaccines $(1,14)$. Although $\mathrm{BoHV}$ isolates are regarded as stable, small antigenic variations may occur and it is possible that autochtonous isolates are more antigenically representative of viruses that are affecting a specific geografical region. Therefore, we developed an autochtonous $\mathrm{gE}^{-} \mathrm{BoHV}-1$ so that, with the use of an anti-gE serological test, the immune response to the vaccinal virus can be differentiated from that induced by wild type virus, and yet retaining most of the antigenic characteristics common to local BoHV-1 isolates. Other $\mathrm{gE}^{-}$bovine herpesviruses have been described $(1,11,15,18)$, however, this is the first report on the introduction of a whole gE deletion on a BoHV-1.2 strain. An option was made for a BoHV-1.2a in view of the fact that isolates of this subtype not only may cause respiratory disease but may also be involved in reproductive disorders, causing miscarriage $(3,15)$. Consequently, this vaccinal candidate may induce protection against both respiratory and reproductive disease.
The induction of the $\mathrm{gE}$ deletion was investigated by restriction endonuclease and Southern blot analysis. The pattern of bands obtained by digesting the wild type viral DNA with HindIII and EcoRI was according to the restriction maps of the BoHV-1.2 K22 strain (8). Digestion of deleted viral DNA showed a new pattern of bands, with the disappearance of HindIII L band, which corresponded to the loss of a HindIII site inside the gE gene. Also due to the loss of this HindIII site, we observed the production of two new fragments after fusion of Hind III $\mathrm{L}$ with $\mathrm{C}$ and $\mathrm{L}$ with $\mathrm{F}$ bands. Genomic alterations in EcoRI digested DNA were according to insertion of additional $E c o$ RI sites in the deletion fragment, giving rise to two new DNA fragments of about 11.6 and $4.2 \mathrm{~kb}$. These results confirmed the induced deletion of the $\mathrm{gE}$ gene from the viral genome, as well as the absence of $\mathrm{gE}$ expression in infected cells. No additional genomic changes were found, indicating that no other major rearrangements were produced as a result of extra unintended recombination events.

Previous studies were performed to access the in vitro behavior of $\mathrm{gE}^{-} \mathrm{BoHV}-1.1$ mutants $(1,11)$. In order to determine the in vitro growth behavior of the $\mathrm{gE}^{-} \mathrm{BoHV}-1.2$ and to make comparative analysis between BoHV-1.1 and BoHV-1.2, growth kinetics and viral plaque size of viruses will be determined. Also, the in vivo effect of infection with deleted virus will be determined by animal experimental infection, in order to access its potential as a vaccine candidate strain.

\section{RESUMO}

\section{Construção e caracterização de uma amostra de BoHV-1.2 isolada no Brasil com uma deleção no gene da glicoproteína $\mathbf{E}$}

Este artigo descreve a construção e caracterização de uma amostra de um herpesvírus bovino tipo 1.2a (BoHV-1.2a) que apresenta uma deleção na região genômica que codifica a glicoproteína $\mathrm{E}(\mathrm{gE})$. A deleção gênica foi induzida através da co-transfecção de um fragmento de deleção, contendo as regiões 5'e 3 flanqueadoras da gE, com o DNA viral intacto de uma amostra viral isolada de um animal que apresentava doença respiratória. O isolamento do vírus gE negativo ( $\mathrm{gE}^{-}$) foi realizado com auxílio da técnica de imunoperoxidase em que foi utilizado como anticorpo primário um anticorpo monoclonal anti-gE. O vírus $\mathrm{gE}^{-}$foi purificado e o DNA isolado desta amostra foi examinado através das técnicas de análise por enzimas de restrição e "Southern blot". Esta amostra gE" será avaliada como candidata para compor uma vacina diferencial contra a rinotraqueíte infecciosa dos bovinos.

Palavras-chave: rinotraqueíte infecciosa/vulvovaginite infecciosa dos bovinos, BoHV-1, vírus deletado, vacina diferencial 


\section{REFERENCES}

1. Chowdhury, S.I.; Ross, C.S.D.; Lee, B.J.; Hall, V.; Chu, S. Construction and characterization of a glycoprotein E gene deleted bovine herpesvirus type 1 (BHV-1) Recombinant Virus. Am. J. Vet. Res., 60: 227-232, 1999.

2. Edwards, S.; Newman, R.H.; White, H. The virulence of british isolates of bovid herpesvirus 1 in relationship to viral genotype. Brit. Vet. J., 147: 216-231, 1991.

3. Gibbs, E.P.J. and Rweyemamu, M.M. Bovine herpesviruses. Part I. The Vet. Bull., 47: 317-343, 1977.

4. Graham, F.L. and van der Eb, A.J. A new technique for the assay of infectivity of human adenovirus 5 DNA. Virol., 52: 456-467, 1973.

5. Kaashoek, M.J.; Moerman, A.; Madic, J.; Weerdmester, K; Rijsewijk, F.A.M.; van Oirschot, J.T. An inactivated vaccine based on a glycoprotein E-negative strain of bovine herpesvirus 1 induces protective immunity and allows serological differentiation. Vaccine, 13: 342-346, 1995.

6. Kramps J.A.; Magdalena J.; Quak J.; Weerdmeester K.; Kaashoek M.J.; Maris-Veldhuis M.A.; Rijsewijk F.A.; Keil G.; van Oirschot J.T. A simple, specific, and highly sensitive blocking enzyme-linked immunosorbent assay for detection of antibodies to bovine herpesvirus 1. J. Clin. Microbiol., 32: 2175-81, 1994.

7. Leung-Tack, P.; Audonnet, J-C.; Riviere, M. The complete DNA sequence and the genetic organization of the short unique region (Us) of the bovine herpesvirus type 1 (ST strain). Virol., 409-421, 1994.

8. Mayfield, J.E.; Good, P.J.; van Oort, H.J.; Campbell, A.R.; Reed, D.E. Cloning and cleavage site mapping of DNA from bovine herpesvirus 1 (Cooper strain). J. Virol., 47: 259-264, 1983.
9. Metzler A.E.; Matile H.; Gassmann U.; Engels M.; Wyler R. European isolates of bovine herpesvirus 1: a comparison of restriction endonuclease sites, polypeptides, and reactivity with monoclonal antibodies. Arch. Virol., 85: 57-69, 1985.

10. Miller, J.M.; Whetstone, C.A.; Bello, L.J.; Lawrence, W.C. Determination of the ability of a thymidine kinase-negative deletion mutant of bovine herpesvirus-1 to cause abortion in cattle. Am. J. Vet. Res., 52: 1038-1043, 1991.

11. Rebordosa, X.; Piñol, J.; Pérez-Pons, J.A.; Lloberas, J.; Naval, J.; Querol, E. Mapping, cloning and sequencing of a glycoproteinencoding gene from bovine herpesvirus type 1 homologous to the gE gene from HSV-1. Gene, 149: 203-209, 1994.

12. Sambrook, J.; Fritsch, E.F.; Maniatis, T. Molecular cloning: A Laboratory Manual, Cold Spring Harbor Laboratory, New York, 1989.

13. Schwyzer M. and Ackermann M. Molecular virology of ruminant herpesviruses. Vet. Microb., 53: 17-29, 1996.

14. Strube, W.; Auer, S.; Block, W.; Heinen, E.; Kretzdorn, D.; Rodenbach, C.; Schmeer, N. A gE deleted infectious bovine rhinotracheitis marker vaccine for use in improved bovine herpesvirus 1 control programs. Vet Microbiol., 53: 181-9, 1996.

15. Van Engelenburg, F.A.C.; Kaashoek, M.J.; Rijsewijk, F.A.M.; van den Burg, L.; Moerman, A.; Gielkens, A.L.J.; van Oirschot, J.T. A glycoprotein E deletion mutant of bovine herpesvirus 1 is avirulent in calves. J. Gen. Virol., 75: 2311-2318, 1994.

16. Van Oirschot, J.T. Bovine herpesvirus 1 in semen of bulls and the risk of transmission: a brief review. The Vet. Quart., 17: 29-33, 1995

17. Whitbeck J.C.; Knapp A.C.; Enquist L.W.; Lawrence W.C.; Bello L.J. Synthesis, processing, and oligomerization of bovine herpesvirus $1 \mathrm{gE}$ and gI membrane proteins. J. Virol., 70:7878-84, 1996.

18. Yoshitake, N.; Xuan, X; Otsuka, H. Identification and characterization of bovine herpesvirus-1 glycoproteins E and I. $J$. Gen. Virol., 78: 1399-1403,1997. 